\title{
多様な人材の参加による園芸福祉活動の課題と可能性
}

\section{Issues and possibilities of horticultural well-being activities with the participation of various}

唐崎 卓也* 石井 麻有子** 岩崎 寛 ${ }^{* * *}$

\author{
Takuya KARASAKI Mayuko ISHII Yutaka IWASAKI
}

\begin{abstract}
This study analyzed the development process of horticultural well-being activities, based on the case study of "Funakata Farm" at Noda City in Chiba Prefecture. The issues and possibilities of horticultural well-being activities were clarified with the participation of various actors. Through the process of activities, the workshop helped to effectively grasp the issues, such as shortage of hands and lack of funds, and to design future vision. Furthermore, specialized knowledge on horticulture and welfare is required in order to extend these activities to persons with disabilities and elderly persons. This would be possible by cooperation with welfare facilities and research institutes.
\end{abstract}

Keywords: horticultural well-being, workshop, the citizen participation, utilization of abandoned farmland キーワード：園芸福祉, ワークショップ, 市民参加, 遊休農地活用

\section{1. はじめに}

農と福祉の連携が近年注目されている。農業分野からは，農作 業に障害者や高齢者の参加を得ることで, 新たな担い手の確保や 遊休農地の解消が期待でき, 福祉分野からは, 障害者や高齢者の 健康増進や，就労の場の確保が期待されている。農と福祉の連携 は，農業分野，福祉分野の双方からのニーズがあり，既に農業分 野での障害者就労に関する取り組みや研究が進みつつある 1),2,3)。

これまで，障害者や高齢者などを主な対象とし，癒しや健康増 進といった福祉的な効果を目的に行う植栽活動は，広く園芸福祉 と呼ばれてきた。松尾は園芸福祉を，「園芸のもつさまざまな効用 を活用しながら，生活の質の向上，健康の維持増進をはかり，さ らには療法的専門技能を必要とする介護やケア，リハビリテーシ ヨン，治療を行うことまで広範な活動を含む」と述へ 4)，活動に は，高度な知識と技術を有する専門家の支援が欠かせないとして いる。園芸福祉は，日本でも普及が図られ，2001 年には日本園芸 福祉普及協会が設立され，園芸福祉講座の開設や，人材育成が進 められている。また, 日本園芸療法学会が認定する園芸療法士の 資格制度が 2005 年から開始されるなど，園芸福祉，園芸療法に 関わる高度な技術を持った専門家の育成が進められている。

こうした園芸による癒しや健康増進効果に関する研究は, 松尾 5)，岩崎6)などの研究蓄積がみられる。一方，園芸福祉に関する実 践活動に目を向けると, 様々な主体が各地で活動を行っており,

その内容も多様である 7)。多くの活動は，社会福祉施設や医療機 関等が単独で行っている。これらの事例では，園芸福祉活動を行 う農的空間，すなわち農場あるいは園地を，同一の施設の関係者 と利用者が管理するのが一般的である。障害者やハンディキャッ プを持つ高齢者が園芸作業に関わるには，専門性を有する人材に よるサポートが必要となる。また，作物や植物の育成には継続的 な管理が不可欠となる。このため, 福祉や医療の専門家を有する 施設が単独で行う活動は，専門性や継続性に優位性がある。

一方，厚生労働省は，地域の中で住まい・医療・介護・予防・
生活支援が一体的に提供される「地域包括ケアシステム」の構築 を，超高齢化社会を見据えた施策的な目標として示している 8)。 そこでは，多様な主体による生活支援・介護予防サービスの重層 的な提供が求められ，園芸福祉が果たす役割は大きいと考えられ る。今後, 多様な人材の参加による福祉コミュニティの形成や, 地域づくりの視点からのアプローチが求められる。しかし，地域 包括ケアの視点からの園芸福祉に対する研究アプローチとしては, 半澤 9)が高齢者による農作業が地域包括ケアの一環となる可能性 があることを示した以外に，研究蓄積はみあたらない。

また，施設単体の活動にとどまらず，地域の連携によって園芸 福祉活動が持続的に運営されている事例としては，埼玉県の「見 沼たんぼ福祉農園」が挙げられる。石井ら 10) は, 同農園の活動展 開をもとに福祉農園の運営形態のモデル化を行うなかで, 在来の 緑地保全活動や地域資源の中に福祉的活動の受容力を見出し, そ のポテンシャルの高、場所に，福祉的活動を導入する計画論が必 要であるとした。しかし，多様な人材の参加による園芸福祉活動 を持続的に行うための実践的な知見は明らかにされていない。

本研究では，千葉県野田市の「園芸福祉ファーム・お〜い船形」 の事例分析をもとに，持続的な園芸福祉活動を行ううえでの課題 を抽出するとともに，実践的な知見として，活動が成立するため の要因や活動の新たな可能性を考察することを目的とする。

\section{2. 研究方法}

\section{(1) 対象事例の概要}

本研究は千葉県野田市の「園芸福祉ファーム・お〜い船形」（以 下，船形農場）を対象に調査，分析を行った。船形農場での園芸 福祉活動は, 2004 年に始まり, 主に定年退職後のシニア世代のボ ランティアによって運営されている。農場では, NPO 法人や生 活協同組合の支援のもと, 野田市や市内の社会福祉施設と連携し ながら，主に市内の社会福祉施設に入所している障害者を受け入 れ，野菜の播種，収穫などの園芸福祉活動を行っている。

*農研機構農村工学研究所 *医療法人社団至高会たかせクリニック *葉大学大学院園芸学研究科 
農場は，活動開始から 10 年以上が経過していることから，持 続的な活動を行ううえでの課題や活動展開の可能性について考察 するには適した事例といる。

筆者らは, 2013 年から専門家としてワークショップの企画, 園 芸福祉に関する情報提供，農場再編の構想づくりに関わった。

園芸福祉に関わる事例を既往文献 7) から整理すると, 活動の主 体は, 研究会などの任意組織, 社会福祉施設, 学校, NPO 法人, 民間企業, 病院, 生産者組織, 農業協同組合に分類される。また, 活動に利用される空間は，社会福祉施設が管理する敷地内，公共 施設の園地，農地，市民農園，公園，建物内（プランターを使つ た講習) などが該当する。

船形農場は，運営主体はボランティアを中心とする任意組織で あるが，事務局機能を NPO 法人が担っており，NPO 法人を核と する協働型の任意組織といえる。活動の場所は，市から斡旋を受 けて地元農家から借地した遊休農地であり，遊休農地の活用と園 芸福祉の両面での効果が期待される活動といえる。また，農場で は農産物直売所等への出荷を毎日行うなど，本格的な農業生産を 行っており，自立した経営を行っている点も特徴といえる。

\section{(2) 調査方法}

調査にあたっては，船形農場の開設時から農場の事務局的な役 割を果たしてきた I 氏（女性）および関係者からの聞き取りを行 った。また, 活動の過程で 2013 年 11 月から継続的に 7 回実施し たワークショップにおいて, 農場で活動する会員の意見を抽出,

整理した。そして，筆者らが農作業等の活動に参加するなかで得 られた観察結果を加えて, 園芸福祉活動の課題, 活動成立の要因 と可能性について，分析と考察を行った。なお，船形農場の開設 は2006 年であるが, 活動自体は 2004 年から行われており, その 期間も船形農場の活動として分析対象に含めることとした。

\section{3. 船形農場の活動展開}

\section{(1) 活動の背景}

野田市は,「高齢者, 障がい者に優しいまちづくり」に早くから 力を入れ，1995 年 9 月には庁内にプロジェクトチームを設置す るなど, 福祉施策の検討を進めた。市は, 1997 年度を「福祉のま ちづくり元年」と位置づけ，「福祉のまちづくり運動推進協議会」 を設置した。以降，市や事業者などが連携し，障害者や高齢者一 の配慮を行い，日常生活や社会生活を営む上での心理的，物理的 な障害を取り除く, バリアフリー化を推進している。

また，野田市には，「野田市手をつなぐ親の会」や「野田市障が い者団体連絡会」など，障害者福祉に取り組む市民ネットワーク があり，市との連携のもと活動を行っている。

こうしたなか，市は福祉施策を重点的に進める地区として，福 祉ゾーンを設定した。市の中心地に近い鶴奉地区を第一の福祉ゾ ーンに，市北部にある船形地区を第二の福祉ゾーンに設定し，社 会福祉施設や関連施設の整備を進めている。なお，図一 1 に示し た第二の福祉ゾーンである船形地区には, 2006 年に障害福祉サー ビス事業所が開設, 2008 年には公設民営型の農産物直売所「ゆめ あぐり野田」が開設された。同店は，障害者を雇用するほか，売 場には園芸福祉コーナ一の棚を設け，船形農場専用の販売スペー スを確保するなど，福祉に力を入れたユニークな取り組みを行っ ている。

\section{（2）活動の展開}

船形農場での活動は，野田市内に店舗を持つ県内の生活協同組 合エル (現パルシステム千葉) が，地域に貢献できる取り組みと して園芸福祉に注目し，野田市に協働を呼び掛けたことに端を発 する。当時，同生協の介護事業の担当職員であった I 氏は，農業 を通じて土に触れ合うことが，高齢者にとっての生きがいにつな がると考え，園芸福祉に着目した。また，市が遊休農地増大の問

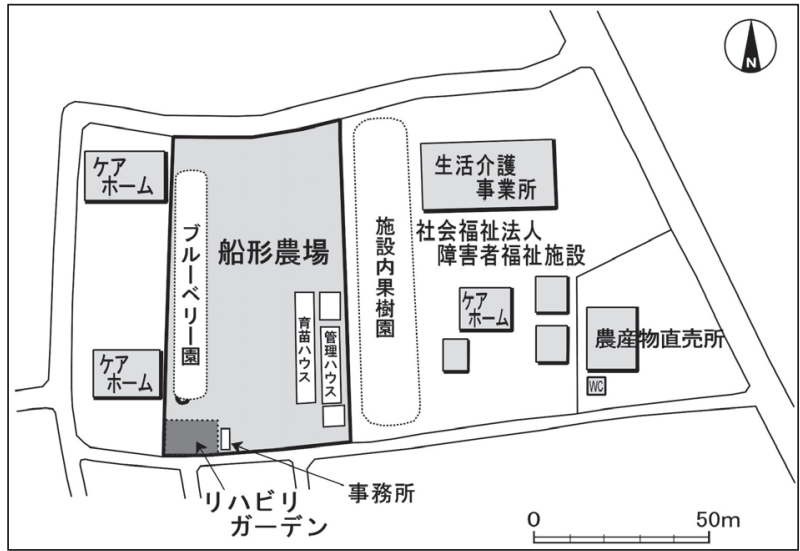

図ー1 野田市第二の福祉ゾーン・船形農場周辺図

表-1 活動の背景と経過

\begin{tabular}{|c|c|}
\hline 時 期 & 活動概要 \\
\hline 1997 年 & 野田市が「福祉のまちづくり元年」とする \\
\hline 2004 年 5 月 & $\begin{array}{l}\text { 野田市の第一福祉ゾーンである鶴奉地区の } 10 \mathrm{a} \text { の農地 } \\
\text { に障害者が参加して, 市の特産品であるエダマメ栽培。 } \\
\text { 障害者とボランティアが } 100 \text { 名参加 }\end{array}$ \\
\hline 2005 年 6 月 & 野田市障がい者団体連絡会が発足 \\
\hline 2005 年 9 月 & 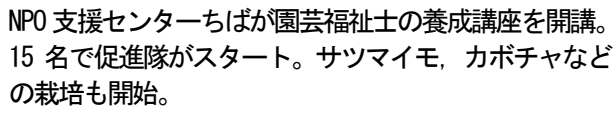 \\
\hline 2006 年 & $\begin{array}{l}\text { 野田市の第二福祉ゾーンである船形地区の } 50 \mathrm{a} \text { の農地 } \\
\text { に活動の場を移転。現在の「園芸福祉ファーム・お } \\
\text { い船形」を埑設 }\end{array}$ \\
\hline 2006 年 6 月 & 農場に隣接して障害福祉サービス事業所が開設 \\
\hline 2008 年 & 促進隊は 26 名に \\
\hline 2008 年 6 月 & $\begin{array}{l}\text { 公設民営型の農産物直売所「ゆめあぐり野田」が船形 } \\
\text { 地区にオープン }\end{array}$ \\
\hline 2012 年 12 月 & 生協の直営農場が農業生産法人として発足 \\
\hline 2013 年 11 月 & 第1回ワークショップ開催。以降，計7回実施 \\
\hline 2014 年 1 月 & 市内愛宕地区にコミュニティカフェ「蔵楽」開店 \\
\hline 2014 年 8 月 & 農場内でリハビリガーデンの造成に着手 \\
\hline 2014 年 10 月 & 大学による農作業プログラムの実施（計4回） \\
\hline
\end{tabular}

題を抱え, 社会福祉施設は障害者の自立が課題とされていたこと から, 両方の問題を解決する活動として, 園芸福祉を生協に提案 した。

表-1 に示すように 2004 年には, 市が第一の福祉ゾーンと位 置づける鶴奉地区の農地 $10 \mathrm{a}$ を活用して, 障害者とボランティア の計100名が参加し, 市の特産品であるエダマメ栽培に取り組み, 苗植え，除草，収穫などの作業を行った。エダマメ栽培に必要な 収穫から販売までの運営とコーディネイトの役割は, 生協が設立 した特定非営利活動法人「NPO 支援センターちば」が担った。I 氏は, 生協からの出向職員としてNPO 支援センターちばに所属 しながら, 船形農場の運営に活動のコーディネイターとして深く 関与することとなった。

農作業に参加する障害者への呼びかけは，市が障害者団体を通 じて行っている。農作業に参加寸るのは, 市内の身体, 精神, 知 的障害者と家族，施設職員であり，農作業の指導は地元農家が担 当した。

しかし，農地を管理し，障害者に農作業を指導するには，ボラ ンティアの人材確保が必要となった。このため, NPO 支援セン ターちばが，ボランティアの募集や人材育成を行うこととした。 同センターは, 2005 年 9 月に, 日本園芸福祉普及協会が認定す る初級園芸福祉士養成講座を企画し, 講座を修了した 15 名がボ ランティアとして, 園芸福祉活動に加わった。ボランティアグル 一プは, 主に定年退職した 60 歳代以上の男女が参加し, 「お〜い 


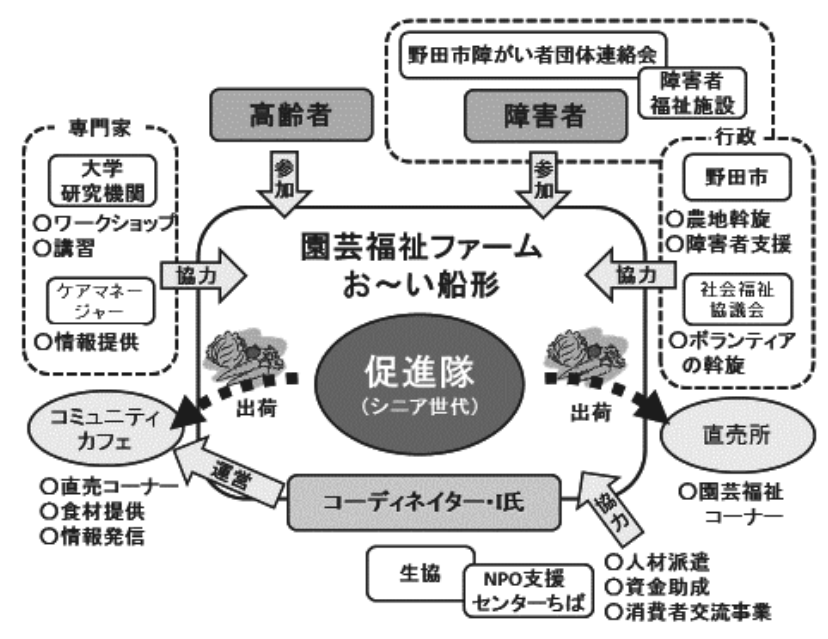

図-2 船形農場の活動の関係者

表一2 農場が備える設備

\begin{tabular}{|c|c|}
\hline 設備 & 内容 \\
\hline 嘈場面積 & "50a（市の斡旋によより近隣の農家から借地） \\
\hline 施設 & $\begin{array}{l}\text { 事務棟, 出荷作業スペース（ビニールハウス） } \\
\text { ビニールハウウス（育苗，野菜栽培用） } \\
\text { キウイ・ブドウのパーゴラ } \\
\text { 保冷庫, 電気·水道（井戸水） } \\
\text { リハビリガーデン }\end{array}$ \\
\hline 農業機械 & $\begin{array}{l}\text { トラクター, 刈り払い機 } \\
\text { (高齢者向きの创り払い機は市から貸借) }\end{array}$ \\
\hline 駐車場 & 約 10 台の駐車スペース \\
\hline
\end{tabular}

船形促進隊」(以下，促進隊）と名付けられた。当初，10a でス夕 ートした農地は, 2006 年には市の第二の福祉ゾーンである現在の 船形地区に移転し，面積は $50 \mathrm{a}$ に拡大した。農地は市役所の斡旋 により地権者である地元農家から借地し，毎年賃貸契約を更新し ている。この農家は船形農場での活動に参加することがあるなど, 活動への理解があり，継続的な農地の利用が可能となっている。

現在，市内の 9 つの社会福祉施設に入所寸る障害者が，数名ず つ施設職員と参加し，エダマメ，さつまいも，大根などの植え付 けから収穫までを体験している。収穫物は，障害者の家族が買い 取っている。また，固場の一部は，生協が主催する農業体験活動 に提供しており，子供を中心に，幅広い年齢層の消費者が農場に 訪れている。図一2 に示寸ように，船形農場の園芸福祉活動は， ボランティアの市民と，NPO 法人，行政，社会福祉施設，専門 家らの連携によって成立している。

\section{（3）農業生産活動}

農場では，年間を通じて約 30 種類の野菜と，ブルーベリー, キウイなどの果実を生産し，農産物直売所に毎日出荷している。 障害者を受け入れる農場であるため, 農薬と化学肥料は使用して いない。有機JAS 認証は受けていないものの, 実質的には有機栽 培と同様の農業生産を行っている。このため, 夏場を中心とした 除草作業には促進隊が大きな労力を費やしている。

表一 2 に示寸ように, 船形農場では, トラクタ一や農業用八ウ ス，保冷庫など，通常の農場に必要な設備一式を保有している。 なお，50a の圃場面積には，事務棟や駐車場などの管理スペース も含まれている。

農作業は，促進隊の活動日として毎週水曜日に行い，苗の植え 付けや収穫, 除草作業などを，ボランティアで行っている（図一 3)。直売所一出荷するための袋詰めなどの調製作業は，主に I 氏 と女性メンバーが担当している。しかし，出荷は毎日行っている ため, 水曜日以外は, I 氏が午前中に収穫から出荷までの作業を

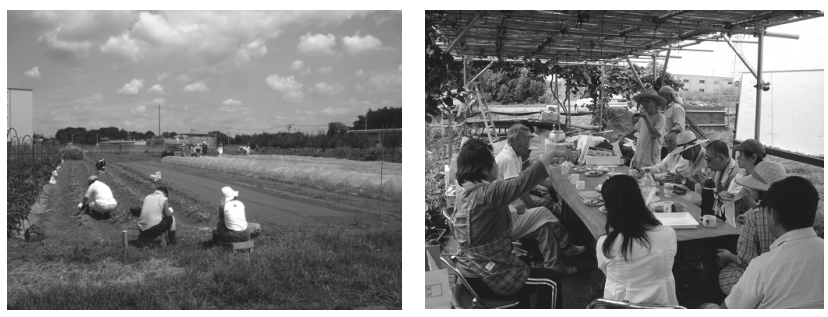

図一３船形農場の固場と促進隊

行っている。また I 氏以外にも, 促進隊メンバーが曜日を決めて, 定額の賃金によるパートタイムまたはボランティアで出荷作業に 加わっている。このうち日曜日の作業を担当している促進隊の 50 代男性会社員が中心となり，ニンニクの加工品である黒ニンニク のオーナ一制を開始した。このオーナ一制は，年会費 13,000 円 として消費者へ会員募集し, 2015 年度には 16 名が契約している。 オーナ一制による会費収入は，農場の収益に組み込まれている。

船形農場による直売所での販売額は，1 ケ月あたり約 10～20 万円であり，上記のオ一ナ一制やイベント販売などを含めると年 間 200 万円を超える収益をあげている。

農場の収益には，これら農場内の生産物の売上げ以外にも，生 協や福祉関連の民間財団等からの助成が含まれている。加えて, 野田市の第 3 セクターである農業生産法人「野田共生ファーム」 が同市内の江川地区で運営する水田型市民農園を活用し，生協が 主催する農業体験活動を運営する委託費も収益に含まれるが，年 閒数十万円の範囲にとどまる。農場の活動全体として, 農業生産 による収益は, 活動予算の 5 割を超える大きなウエートを占めて いる。以上から, 船形農場の持続的な運営には, 安定した農業生 産が欠かせない要素となっている。

\section{(4) 顕在化する課題}

農場では活動開始から 10 年以上が経過し, 活動実績が積み上 げられる一方, 様々な課題が顕在化しつつある。I 氏への聞き取 りと促進隊による農作業を観察した結果から, 農場の課題を以下 の 3 点から整理する。

1) 労働力・人材の不足

活動初期から参加する促進隊 15 名は, 高齢化により農作業へ の参加が減少傾向にある。2008 年時点では，メンバーは 26 名ま で増加したが, メンバーは増減しながら, 現在は 20 名に減少し ている。メンバーの年齢層は 80 歳代を最高に，60～70 歳代が中 心となっている。毎週水曜日の農作業に参加する人数は, 平均的 に 10 名前後であり, 農作業の観察によると, 除草作業を中心に 労㗢力は不足しており, 特に雑草が繁茂する夏期には顕著となっ ている。

また，かつては農場での活動日は水曜日と金曜日の 2 日間とさ れ，9つの障害者施設がローテーションを組んで作業に参加して いた。このうち軽度障害の入所者 1 名が, 週に 3 日, 賃金労働と して収穫や出荷作業を行った時期もあった。こうした障害者の参 加は，午前中の $10 \sim 11$ 時，時には午後 13 時半から 14 時半とい った定時に行われ, 出荷野菜のパッキングを中心として, 貴重な 労衝力となっていた。

しかし現在, 障害者による日常的な農作業への参加は少ない。I 氏はその理由として，各施設が個別に施設内での農業生産や農作 業体験を行うようになったことや，障害者の来園にあたっては， 施設のスタッフの付き添いが必要であることから, 施設側の人員 不足から来園が困難となっていることを挙げている。

このような状況から I 氏は，活動を持続するためには，農作業 の新たな担い手の確保が不可欠とし，新たに定年退職したアクテ イブシニアや, 農業に関心をもつ学生や一般市民, 就農を目指し た農業技術の習得を希望する若い世代など，幅広い世代の参加を 
表一3 ワークショップの概要

\begin{tabular}{|c|c|c|c|c|c|}
\hline 回 & 開催時期 & ワークショップのテーマ & 参加者·場所 & 内容 & ワークショップの成果 \\
\hline 第1回 & 2013年11月 & $\begin{array}{l}\text { 活動全体のふり返り、 } \\
\text { 課題整理 }\end{array}$ & $\begin{array}{l}\text { 場所 : カフェ蔵楽 } \\
\text { 14名 (促進隊·関係者7名、一般· } \\
\text { 大学生4名、専門家3名) } \\
\end{array}$ & 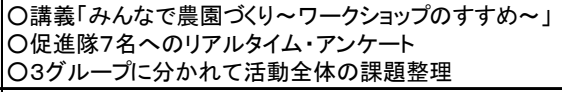 & \begin{tabular}{|l} 
促進隊の意識の把握と今後の活動 \\
に向けた課題が整理された
\end{tabular} \\
\hline 第2回 & 2013年12月 & \begin{tabular}{|l} 
農場の課題、将来構 \\
想
\end{tabular} & $\begin{array}{l}\text { 場所 : 船形農場のハウス·专場 } \\
18 \text { 名 (促進隊·関係者8名、一般· } \\
\text { 大学生7名、専門家3名) }\end{array}$ & $\begin{array}{l}\text { O講義「園芸活動がもたらす健康効果」 } \\
\text { ○インスダン使った農場点検 } \\
\text { O農作業や固場など農場に関する課題や将来構想の意 } \\
\text { 見交換 }\end{array}$ & $\begin{array}{l}\text { 農作業を通じた健康面での効果や } \\
\text { 特産品となる野菜や加工品, 休㮩 } \\
\text { スペースづくりなどが提案された }\end{array}$ \\
\hline 第3回 & 2014年3月 & 農場の具体的将来像 & $\begin{array}{l}\text { 場所 : カフェ蔵楽 } \\
10 \text { 名（促進隊7名、一般4名、専門 } \\
\text { 家3名） }\end{array}$ & $\begin{array}{l}\text { O講義「リハビリテーションガーデンについて」 } \\
\text { O2グループに分かれて農場の将来構想を具体化 }\end{array}$ & $\begin{array}{l}\text { 新たな取り組みとして, 特養施設と } \\
\text { の連携や, 来園者や促進隊が休暞 } \\
\text { でき, 花や果実のつみ取りができる } \\
\text { 空間づくりが提案された }\end{array}$ \\
\hline 第4回 & 2014年8月 & $\begin{array}{l}\text { リハビリガーデンの具 } \\
\text { 体的イメージづくり }\end{array}$ & $\begin{array}{l}\text { 場所 : 船形農場·カフェ蔵楽 } \\
11 \text { 名 (促進隊3名, 大学生4名, ケ } \\
\text { アマネージャー2名, 専門家2名) }\end{array}$ & $\begin{array}{l}\text { O農場の現地確認 } \\
\text { O講義「介護サービスを利用する高齢者の日常生活につ } \\
\text { いて」(ケアマネージャ一から) } \\
\text { O高齢者にやさしいリハビリガーデンの構想づくり(短期・ } \\
\text { 中期の活動案) }\end{array}$ & $\begin{array}{l}\text { ケアマネージャーから介護サービス } \\
\text { を受ける高齢者受け入れの留意点 } \\
\text { が示され, リハビリガーデンの構想 } \\
\text { が提案された }\end{array}$ \\
\hline 第5回 & 2014年10月 & $\begin{array}{l}\text { リハビリガーデンの活 } \\
\text { 用のイメージづくり }\end{array}$ & $\begin{array}{l}\text { 場所 : 船形農場 } \\
\text { 14名 (促進隊5名, 大学生6名, ケ } \\
\text { アマネージャー1名, 専門家2名) }\end{array}$ & $\begin{array}{l}\text { O講義「スウェーデンのリハビリガーデン」 } \\
\text { O農場とカフェに関する情報発信について大学生の提案 } \\
\text { O造成中のリバリガーデン現状確認 } \\
\text { Oリハビリガーデンの活用方法の検討 } \\
\end{array}$ & $\begin{array}{l}\text { 農場とカフェ蔵楽の連携や, リハビリ } \\
\text { ガーデンの活用にこついて構想が練 } \\
\text { られた }\end{array}$ \\
\hline 第6回 & 2014年11月 & \begin{tabular}{|l|} 
造成中のリハビリガー \\
デンに対する専門家に \\
よるアドバイスと検討 \\
\end{tabular} & \begin{tabular}{|l|} 
場所 : 船形農場 \\
7 名 (促進隊3名, 大学生2名, 専 \\
門家2名)
\end{tabular} & $\begin{array}{l}\text { O造成中のリハビリガーデンの現状確認 } \\
\text { Oスウェーデンのリハビリガーデン専門家との意見交換 }\end{array}$ & $\begin{array}{l}\text { リハビリガーデンに設置するデッキ, } \\
\text { レイズドベッドなどの具体的なアイ } \\
\text { ディアが得られた } \\
\end{array}$ \\
\hline 第7回 & 2014年12月 & $\begin{array}{l}\text { これまでのワークショッ } \\
\text { プの成果の総括と次年 } \\
\text { 度活動の検討 }\end{array}$ & $\begin{array}{l}\text { 場所 : カフェ蔵楽 } \\
8 \text { 名 (促進隊3名, 大学生1名, 一 } \\
\text { 般1名, 専門家3名) }\end{array}$ & $\begin{array}{l}\text { O野田市のボランティア制度などの情報提供 } \\
\text { ○第6回ワークショップにおけるスウェーデン専門家の指 } \\
\text { 摘の確認 } \\
\text { O来年度以降に向けてのソフト面の検討 }\end{array}$ & $\begin{array}{l}\text { 新たな参加を募るための活動の方 } \\
\text { 向性を検討した }\end{array}$ \\
\hline
\end{tabular}

期待している。

2）農場管理面での課題

50a の農地のうち，管理スペースを除き，実際に野菜の作付け を行っているのは, 約半分の $25 \mathrm{a}$ 程度にとどまる。約 10 名によ る週 1 回の管理作業では，50aの面積全体を利用した栽培管理や 除草が困難になっている。借地している農地であることから，防 草用の被覆は，撤去が容易な防草シート以外の使用は難しい。農 場の観察によれば，隣接する敷地の境界部や果樹園など，トラク ターによる耕起や刈り払い機の使用が難しい場所もあることから, 夏期には雑草が繁茂する箇所が目立ち始めている。

3）農場のコンセプトの変化

船形農場の発足時には，園芸福祉士養成講座の受講者が中心と なって促進隊を結成したため, 活動のコンセプトとして園芸福祉 が明確に位置づけられていた。しかし，現在も障害者の受け入れ を定期的に行っているものの，前述のように障害者の来園は従来 に比べて少なくなっている。また，新たに促進隊に加わったメン バーは，市の社会福祉協議会のボランティア斡旋によって参加し たケースもあり，活動への参加動機は園芸福祉には限らない。

I 氏は, 農場のコンセプトとしては, 園芸福祉を重要な要素で あるとしつつも，新たなメンバーの参加を募るに際して，農場で の活動メンバー自身の癒しや健康, 安全・安心な食, メンバー間 の交流やレクリエーションといったニーズを取り入れた，新たな コンセプトの構築が必要と考えている。

\section{4. ワークショップを活用した農場再編}

\section{(1) ワークショップの目的}

筆者らは，I 氏からの依頼を受け，前章で把握した活動の課題 の解決に向け，農場での活動の再編に取り組むために，以下の観 点からワークショップの実施を提案した。ワークショップの主な 目的として，1)これまでの活動をふり返り，活動の課題を整理す る。2)専門家からの情報提供・学習を通じ，農場の将来構想づく りを行う，3)ワークショップを通じて新たな人材を発掘する，の 3 点を想定した。

\section{(2) ワークショップの概要}

ワークショップの企画や進行役（ファシリテーター）は, 筆者
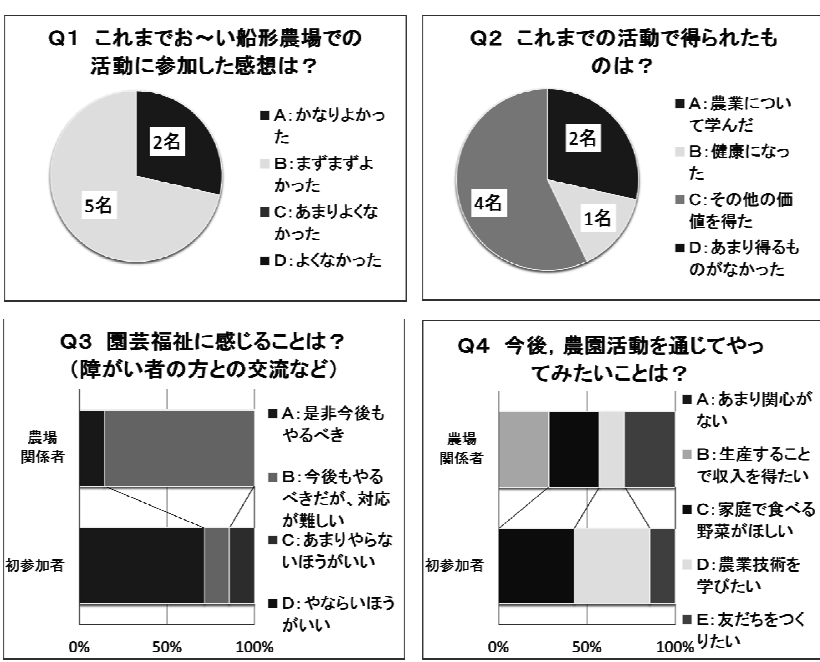

図ー4＼cjkstart第1 回ワークショップ参加者へのアンケート

らが務めた。2013 年 11 月から現在に至るまで計 7 回のワークシ ヨップを実施した。表一 3 にワークショップの概要を示した。

ワークショップには，促進隊のほか，一般市民，大学生から参 加を募った。参加者募集には, 生協の案内や地元広報紙を利用し, 市民に向けて広く参加を呼びかけた。促進隊以外に参加を呼びか けたのは，ワークショップへの参加を契機に，新たなメンバーと しての加入を期待したことや，農場の新たなコンセプトづくりに 第三者からの発想を求めたことによる。

（3）ワークショップで把握された促進隊の意識と活動の課題

第 1 回ワークショップでは, これまでの活動の課題抽出に向け て，ワークショップ参加者に活動への意識に関するアンケートを 行った。図-4のQ1 に示寸ように, 参加した促進隊 7 名からは, これまで活動に参加した感想として，「かなり良かった」に2名, 「まずまず良かった」に 5 名が回答した。促進隊のメンバーはお おむね活動への参加に満足していると考えられる。一方, 眓一 4 の Q2 に示すように, これまでの活動で得られたものとして,「農 業について学んだ」に 2 名, 「健康になった」に 1 名, 「その他の 
価值を得た」に 4 名が回答している。「その他の価值」について は, その後のワークショップでの意見抽出からは，「定年退職後の 仲間ら゙くりができた」、「園芸福祉を学び，障害者を農場に招くこ とを意気に感じた」といった意見が出され，農場での活動に対す る価值意識は多様であることが読み取れる。

また, 園芸福祉に対する意識では, 図一4のQ3 に示すように, 一般の参加者 7 名中の 5 名が,「是非今後もやるべき」と回答し ているのに対し，促進隊メンバーは，7名中 6 名が「今後もやる べきだが，対応が難しい」と回答している。これまでの園芸福祉 活動の意義を感じる一方で，障害者との対応を難しいとする意識 が読み取れる。今後, 農園活動を通じてやってみたいこととして は, 図一4の Q4 に示すように,「生産することで収入を得たい,

「家庭で食べる野菜がほしい」，「友だちをつくりたい」とする回 答が 2 名ずつあり, 今後の活動には園芸福祉に限らず, 幅広い価 值への対応が必要であることを示唆している。

一方, 第 1 回ワークショップでは，農場の活動全般に関わる課 題が明らかにされた。まず，促進隊のメンバーからは，障害者と のコミュニケーションに関する専門的な知識を習得していないた めに, 来園する障害者への対応の難しさが指摘された。このため, 促進隊のメンバーからは，今後の園芸福祉活動に向けて，障害者 に対応できる新たな人材の参加が求められた。また, 活動を行う なかで，支援する側であった促進隊による農作業自体が活動の中 心となり，障害者と交流する機会が減りつつあることが指摘され た。このほか, 福祉施設の職員や障害者の家族との交流が少ない ことも挙げられた。

今後の活動への期待としては，障害者に限らず引きこもりの若 者の受け入れ，高齢者の健康維持や機能回復，予防医学的な側面 で農場が貢献することなどが挙げられた。

第 2 回ワークショップでは, 農場での農業生産や空間に関する 課題を中心に意見交換が行われた。農園の施設面の課題として, 作付計画の明確化や, 真夏の給水作業の負担を考慮した給水シス テムの必要性などが指摘された。また，農場運営に関しては，活 動の運営資金を確保するための方策，若い世代の人材の確保，農 場の企画に関わるリーダー的な人材の育成などが必要とされた。

\section{（4）ワークショップを契機とした新たな取り組み}

第 3 回以降のワークショップでは, 抽出された課題を踏まえて, 解決に向けた将来構想を中心に意見交換を行った。その中で，現 状で取り組める活動として，外部からの来園者や促進隊が休憩で き, 花や果実のつ夕取りなど簡易な園芸作業ができるスペースで あるリハビリガーデンの構想づくりが進められた。第 3 回ワーク ショップで, 休息スペースのイメージや，想定される利用者など についてアイディアを出し合い, 第 4 回から第 6 回のワークショ ップで構想を具体化した。ワークショップと時期を同じくして, 民間財団による助成事業の導入が検討されたことから，事業の活 用を想定して具体的な構想を練ることとなった。

第 4 回ワークショップで，地元のデイケア施設に勤務するケア マネージャーの参加を得て, 高齢者の農場への受け入れに必要な 条件などについて情報提供を受け，リハビリガーデンの基本構想 を検討した。その後, 2014 年 8 月からリハビリガーデンの造成 に着手した。リハビリガーデンには，道路に接した圃場の一角の 約 $100 \mathrm{~m}^{2}$ のスペースに，車い寸や杖を利用する高齢者や障害者の 利用を想定したバリアフリーのスペースを設けることとした。休 唕スペースには，ウッドデッキや，レイズドベッド，花壇などを 設けることとした。施工は，促進隊の中で施工技術をもつメンバ 一が中心となって作業が行われた。また, 駐車場から車いすでリ ハビリガーデンやブルーベリー園にも移動ができるよう，防草シ 一トを敷設した。その後の検証で，車い寸の移動には圑場の凹凸 が妨げになることが判明し, 圃場の均平と防草シートの張り直し
を行うなど，ワークショップでの検討や専門家のアドバイスを受 けながら, 順次改良を加えた。2015 年 3 月にはリハビリガーデ ンは一応の完成をみた。

現在，当初の構想のとおり，介護施設などの高齢者による利用 を図るための検討を行っている。しかし，ケアマネージャーへの 相談をもとに，市内の介護施設を利用するハンディキャップを抱 えた高齢者の受け入れを検討したところ, 乗用車による施設から 農場までの移送のケア，農場内で介護ケアの必要が生じた場合の 対応，施設の利用時間内で農場に来訪する場合に時間的な制約が あることなどから，実現には至っていない。また，農場への来訪 には，介護に関わる人材として施設の専門スタッフあるいは家族 の付き添いが必要とされ,これらの条件を満たすに至っていない。

\section{（5）ワークショップの効果と課題}

船形農場は，園芸福禅を目的として始まった活動であるが，メ ンバーの高齢化が進み，今後の活動の持続が危惧された。促進隊 には, 活動の途中から参加したメンバーが複数おり, それらのメ ンバーは結成の契機となった 2005 年当時の園芸福祉士養成講座 を受講していない。ワークショップによって，メンバーの活動に 対する価值意識は多様であることが確認された。新たな人材の参 加を促すには，園芸福祉を活動の基本に据えつつも，新たな活動 のコンセプトを示す必要があることが示された。ワークショップ は, 園芸福祉活動に関わる関係者の意識や課題を共有し, 専門家 や新たな人材からの発想を受けて, 農場の再編につながる構想づ くりが行われた点で, 有効に機能したといえる。

また, ワークショップへの参加を契機に, 大学研究者やケアマ ネージャーら専門家との関係性を構築し, 専門性を要するリハビ リガーデンづくりや, ハンディキャップを抱える高齢者を農場に 受け入れるための対策に関する知見獲得にもつながった。これら から，ワークショップは，以下の点で効果を示したといえる。1） 園芸福祉活動に対する認識の共有, 2) 専門的な知見の獲得と学習, 3)将来構想の立案，4)新たな人材の参加の契機。

しかし当初, ワークショップの役割には, 一般の参加者に園芸 福祉一の理解を進め, 新たなメンバーとして参加を促進すること を期待したものの, 現在までに, 農場での活動への参加には結び ついいない。園芸福祉は専門性の高い活動であり, ワークショ ップの参加者募集にあたっては, 今回行ったような一般に向けた 公募ではなく, 人的なネットワークを活用して, 課題が顕在化し た地域コミュニティや，関係する市民組織にターゲットを絞った 働きかけが必要であったと考えられる。

\section{5. 園芸福祉活動の成立要因と活動展開の可能性}

以上の船形農場の活動の分析から, 多様な人材の参加が求めら れる園芸福祉活動が成立するための要因や，活動の新たな可能性 を考察する。活動成立の要因として以下の 4 点を挙げ，それぞれ の要因ごとに, 国内の園芸福祉活動の成立の可能性を高めるのに 必要な知見を整理する。

\section{(1) 多様な人材 · 組織の連携}

園芸福祉活動は専門性を要するため, 船形農場のようなボラン タリーな人材によって運営される活動組織では, 様々なハンディ キャップを抱える障害者や高齢者の受け入れには，限界がある。 船形農場では図一2 に示した連携体制を構築したように, 園芸福 祉活動の成立には, 障害者やハンディキャップをもつ高齢者を農 場で受け入れるために, 行政機関, 社会福祉施設のスタッフ, 園 芸福祉や介護, 医療などの知見をもつ専門機関, ケアマネージャ 一などの専門家との連携が不可欠と考えられる。

しかし, 船形農場では, 農作業や農場運営に主体的に関与寸る アクティブシニアの参加と, 介護施設を利用するハンディキャッ プを抱える高齢者の農場での健康増進を意図した受け入れは，十 
分に達成されていない。その要因として，介護施設や高齢者ケア に関する地域連携・支援組織との関係性が構築されていないこと が挙げられる。

厚生労㗢省は, 地域の中で住まい・医療・介護・予防・生活支 援が一体的に提供される「地域包括ケアシステム」の構築を目指 すとしている。地域包括ケアの考え方からすれば，䂆方医学的な 観点から，在宅の高齢者への農場での活動への参加促進が期待さ れる。参加促進には，高齢者厅アに関する地域連携・支援組織の ひとつである地域包括支援センターのような，保健師・社会福祉 士・主任介護支援専門員等の専門家を擁寸る機関との連携が有効 と考えられる。ボランタリーな人材によって運営される園芸福祉 活動は，地域連携・支援組織と協力寸ることで，厚生労働省が求 める多様な主体による生活支援・介護予防サービスの重層的な提 供に寄与し，農場はそれを担う空間としての活用が期待できる。 そして，ワークショップは，こうした新たな人材や組織の参加の 契機として活用でき，関係者間の認識の共有にも有効といえる。

\section{（2）コーディネイト機能と人材}

船形農場の園芸福祉活動の成立には，I 氏が役割を担ったコー ディネイト機能が不可欠であったと考えられる。そのコーディネ イト機能に必要な要素は，1)関係組織・人材との連絡調整（障害 者施設の受け入れ・作業内容の確認等)，2)経営管理（作付計画・ 予算等)，3)園芸福祉に関する専門性，の3つと考えられる。I氏 はかつて介護事業を担当し，福祉分野に通じるとともに，園芸福 祉にも活動以前から取り組んでいた。また，NPO 法人職員とし て船形農場の事務局機能や農業生産の管理を担えたことは, 船形 農場が持続的な活動を行ううえで優位な条件であったといえる。 また, 活動への協力農家から農業に関する知識を得られたことも, 農場の経営管理に有効であったといえる。

しかし,一般的にはこうした人材の確保は難しいと推測される。 コーディネイターとなる人材育成の仕組みが必要であり, 園芸療 法士や園芸福祉士などの育成に関する講座において，地域連携や 活動実践のためのコーディネイト機能に関わる学習を組み込むこ とも，ひとつの方策と考えられる。

\section{（3）農場の作業・休覟環境の整備}

船形農場で農作業に参加しているメンバーは 60８0 歳代のシ ニア世代であり，作業への負荷の軽減や健康面でのケアが必要と なっている。このため，農場内には，防草対策や休憩スペース， 暑さ寒さ対策などの設備が必要となった。船形農場では，農業生 産による収益を確保していることから，こうした設備への投資が 可能となっている。

しかし，予算確保が見込めない活動組織の場合，行政や福祉関 連財団からの助成を獲得することや，地元農家や建築業からのボ ランタリーな協力を得るなどの対応が求められる。

\section{（4）消費者と連携した農場経営}

船形農場の大きな特徵として, ボランタリーな組織でありなが ら, 農業経営体として再生産可能な経営が行われている点が挙げ られる。船形農場では, 近接する農産物直売所への常時出荷によ って一定の収益を挙げているほか, カフェでの販売, 農業体験活 動やオ一ナ一制での収益も加えることで，運営に必要な資金を確 保している。このほか, 収益性が高い切り花の販売を開始し, 今 後は農産加工品の開発, 販売も検討するなど, 農業生産面での収 益確保に力を入れている。

一方，船形農場が農作業での受け入れを行っている障害者の家 族が，収穫された農産物を買い取っており，CSA（Community Supported Agriculture）にみられるような, 生産者と消費者の相 互扶助的な関係が成り立っている。また，I 氏は 2014 年に NPO 法人を定年退職した後も活動を継続するとともに,「コミュニティ カフェ蔵楽」を市内で起業した。カフェには, 農場の余剰野菜を
食材として活用するほか，直売コーナ一を設けるなど，船形農場 との連携を図っている。カフェと農場との連携は, 野菜の供給だ けでなく, 農場の活動に関する情報発信や農産加工品の開発など, 様々な効果をみせつつある。

農場による園芸福祉活動の持続には，サービスを提供する農場 側の経営を, 享受する側が消費者として買い支える仕組みが有効 と考えられる。それには，高齢者や障害者が利用する飲食サービ スを始めとする地域の事業体と農場との連携に, 新たな活動の可 能性が見いだせる。

\section{6. おわりに}

本研究は，千葉県野田市「園芸福祉ファーム・お〜い船形」の 事例調査をもとに, 園芸福祉に取り組む農園の開設から現在に至 るまでの活動プロセスを分析し，多様な人材の参加が求められる 園芸福祉活動の運営の課題, 活動成立の要因と活動の新たな可能 性を明らかにした。船形農場は, 定年退職後の高齢者を中心とし たボランティアによって運営されている。農場では, 遊休農地を 活用し, 知的障害者や生協の消費者会員などを対象とした農業体 験活動を行っている。農場では，生産された農産物を直売所等を 通じて販売することで収益を確保しており, 持続的な農場経営が 行われている。また, 農場での園芸福祉活動には, ボランティア の非農家の高齢者だけでなく, 農家, NPO 法人, 社会福祉施設 などの多様な人材が参加することで, 円滑な活動が行われている。

しかし, 活動の開始から 10 年が経過し, 初期の活動メンバー の高齢化による労力不足と, それに伴う農産物の生産量の低下が 課題となっている。こうした課題の解決と将来構想の立案, 新た な人材の参加の契機などに，ワークショップの導入が有効である と考察した。また, 園芸福祉活動の成立には, 多様な人材・組織 の連携, コーディネイト機能と人材, 農業の作業・休憩環境の整 備, 消費者と連携した農場経営, の 4 つの要因が必要であり, そ れには地域包括厅アの視点に立った地域連携や，コーディネイタ 一となる人材の育成などが有効であると考察した。

謝辞：本研究において「園芸福祉ファーム・お〜船形」の関係 者皆様にご協力を賜りました。心より御礼申し上げます。

\section{補注及び引用文献}

1）大澤史伸（1995）: 農業分野における知的障害者の雇用促進システムの 構築と実践: みらい, $141 \mathrm{pp}$

2）近藤龍良編著 (2013) : 農福連携による障がい 者就農 : 創森社, 168pp

3）吉村亜希子・石田憲治（2013）: 都市農村交流や地域活動における障が い者の農作業体験 : 農業および園芸 88(1)，183-187

4）松尾英輔（2005）: 園芸福祉はいま-誕生, 現状, そして, 展望 : 園芸学 研究 4(4), 373-378

5) 松尾英輔 (2002)：植物の不思議パワーを探る一心身の癒しと健康を求め

て : 九州大学出版会, 3-44

6) 岩崎寛 (2007) : 最新環境緑化工学 : 朝倉書店, $65-75$

7) 進士五十八・吉長成恭・近藤龍良監修 日本園芸福祉普及協会編 (2008)： 園芸福祉 地域の活動から : 創森社, 182pp

8）厚生労衝省 : 地域包括ケアシステム : 厚生労働省ホームページ 〈http://www. mhlw. go. jp/stf/seisakunitsuite/bunya/hukushi_kaigo/k aigo_koureisha/chiiki-houkatsu/>, 2015. 9.18 参照

9）半澤由加（2015）: 地域包括ケアを目的とした高齢者に対する農作業の 可能性一野田市の農場を事例として:千葉大学修士論文発表会[園芸学研 究科緑地環境学コース]要旨集, 93-96

10）石井秀樹・齋藤馨・猪野浩平（2006）：埼玉県「見沼田んぼ福祉農園」 の成立と展開にみる都市近郊緑地の福祉的活用の考察 : ランドスケープ 研究 69(5), 767-772 